\title{
INVESTIGATION OF AN ELECTRIC SHAFT FURNACE, DOMNARFVET, SWEDEN.
}

\author{
By EUGene haANel, Ph.D. (Director of Mines).
}

\author{
(Abstract of a Report made to the Department of Mines of the Canadian \\ Government.)
}

\section{INTRODUCTION.}

In the winter of $1905^{-6}$ a series of experiments in electric smelting was conducted at Sault Ste. Marie, Ontario, under the auspices of the Dominion Government, with the object of establishing the feasibility of economically smelting Canadian magnetic iron ores comparatively high in sulphur but free from manganese, and using charcoal as the reducing agent.

As a result of these experiments the electrometallurgy of the reduction of refractory iron ores without the use of coal or coke fuel was established, and - as far as could be expected from a small, experimental furnace-the output of pig iron per electrical horse-power year, determined. Moreover, based upon the experience thus gained certain fundamental changes and improvements, necessary in the construction of an economic electric furnace in the future, were suggested, in order to render it suitable for the production of pig iron on a commercial scale.

Although the Canadian experiments of $1905^{-6}$ proved entirely successful as regards the special objects aimed at, and while considerable interest in the reduction of iron ores by the electrothermic process was manifested at the time, no additional experimentation of any significance has been undertaken in Canada, along the lines suggested in the Mines Branch report, to ensure the commercial success of electric smelting. In Sweden, however, where the conditions governing the economical use of the raw material necessary for an iron industry are very similar to those existing in Canada, the importance of an economic, commercial, electric smelting process was fully realised by three young Swedish engineers some two years ago. These engineers, viz., Assar Grönwall, Axel Lindblad, and Otto Stalhane, stimulated by the successful results of the work done at Sault Ste. Marie, undertook to solve the problem of designing and constructing a commercial electric furnace.

Inasmuch as the electro-metallurgy of the reduction of iron ores had been established by the Canadian experiments, these Swedish inventors concentrated their entire efforts in an attempt to solve the practical, commercial problem along the lines suggested in the official report. In carrying out their plans to a successful issue they were ably assisted by the ironmasters of Sweden, who manifested great interest in this question. Special assistance was rendered by the able and far-sighted director, E. J. Ljungberg, and the vice-director, Lars Yngström, of the largest and most influential industrial company in Sweden, the Stora Kopparbergs Bergslags Aktiebolag. The inventors made an agreement with this company, and the Trafikaktiebolaget 
Grangesberg, Oxelösund (owners of the largest iron-ore deposits in Sweden), to carry on smelting experiments on a large scale at the Domnarfvet iron works.

In order to concentrate their undivided attention on this problem the inventors formed a company called the Aktiebolaget Electrometall, to which the patent rights were assigned.

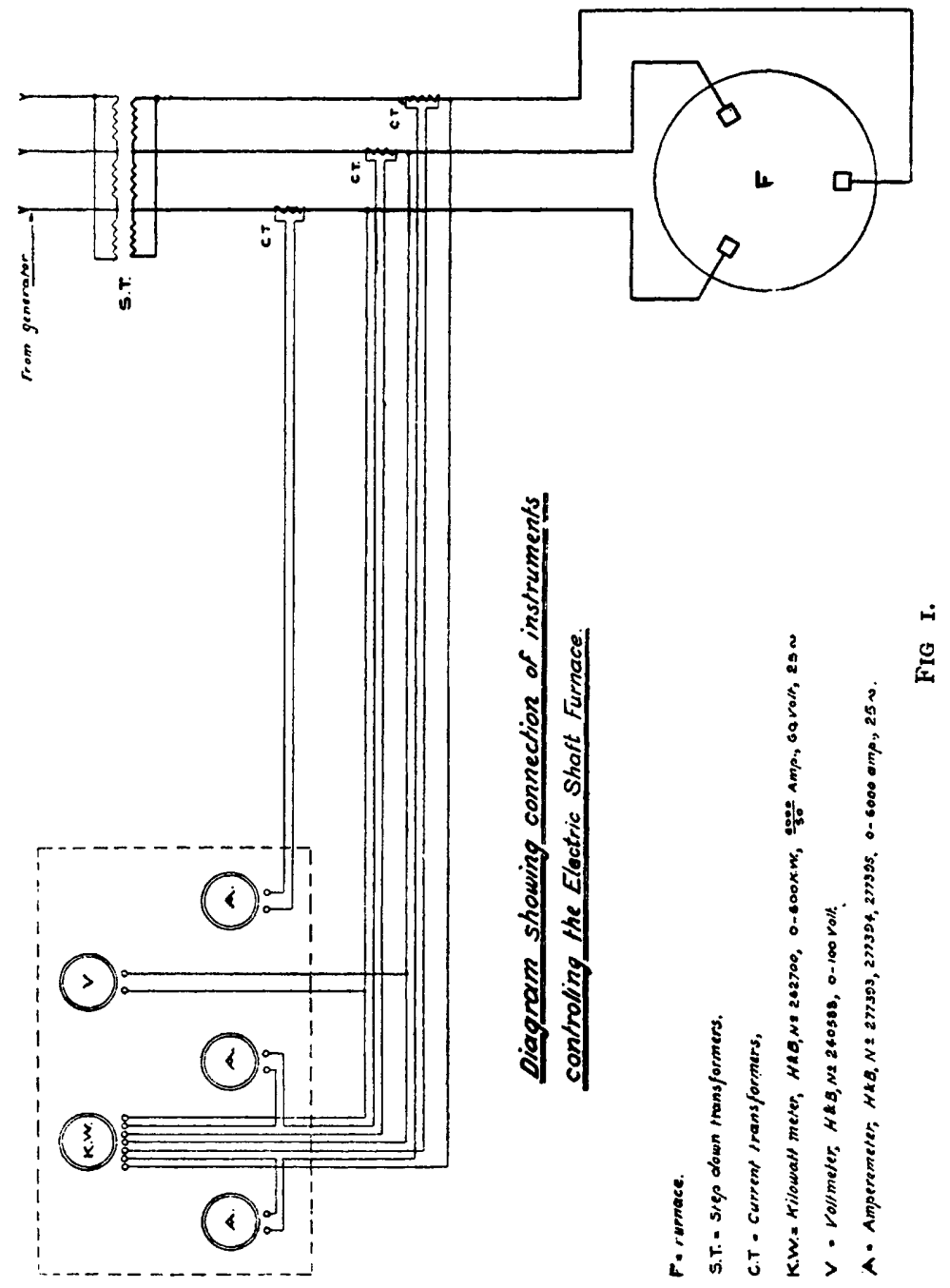

Description of the Plant.

The experimental plant was installed in an old building adjoining the basic Bessemer converter house.

The machinery consists of a 3-phase synchronous motor of about 900 h.p., supplied with a current at 7,000 volts and 60 periods, from a 3-phase cableline in the iron works. This motor is directly coupled to a 3-phase generator, which supplies current of 25 periods, adjustable to between 300 and I,200 
volts, through small intervals to the transformers erected in the immediate vicinity of the furnace.

By means of this extensive regulation it is possible to determine the most suitable voltage to be employed with furnaces of different construction, and operating under various conditions.

The fields of both the synchronous motor and the generator are fed with current at 220 volts, from a direct-current generator, $20-\mathrm{kw}$. capacity, directly

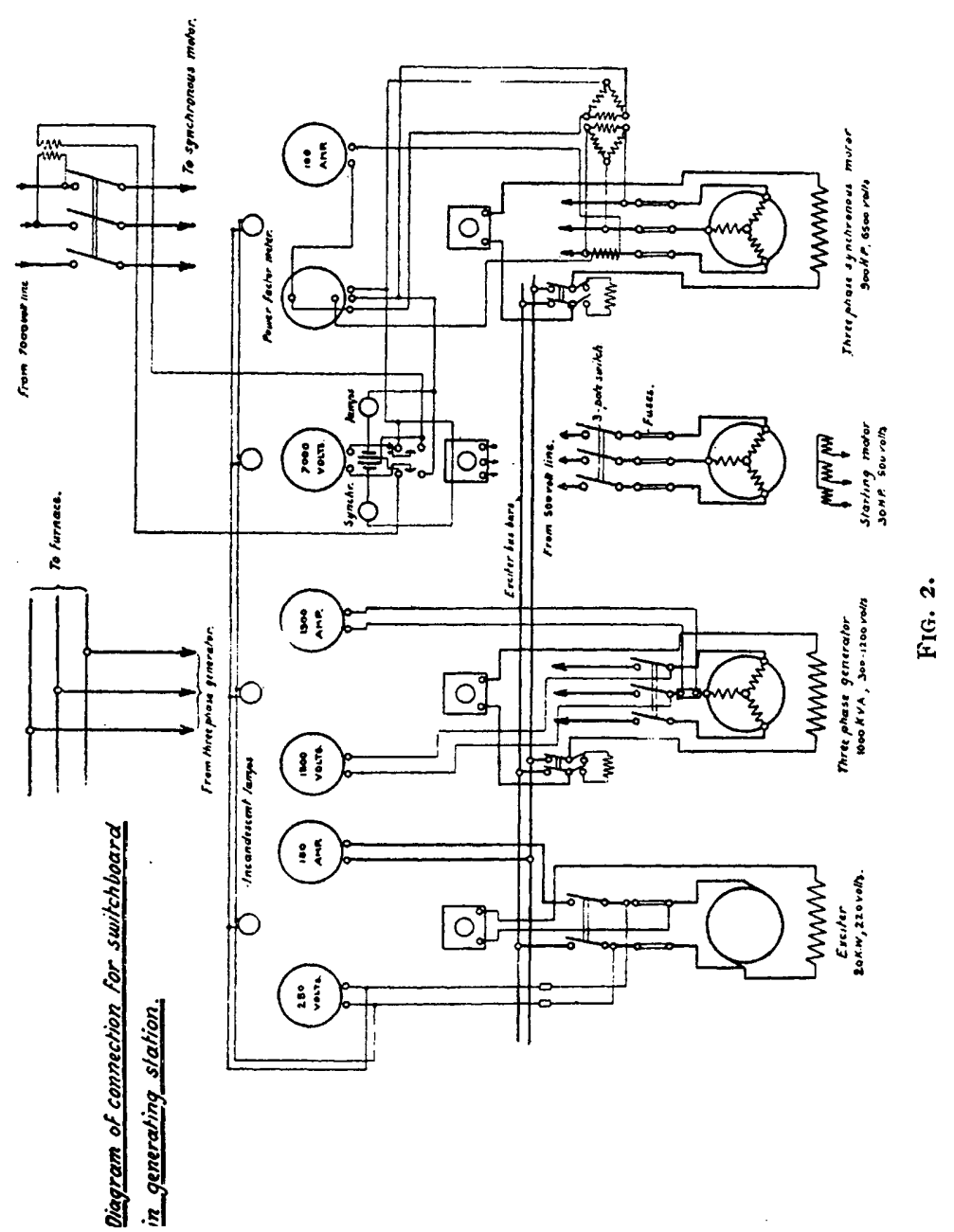

coupled to the system. For starting the system a 3-phase synchronous motor, directly coupled, is employed. This is fed with a current stepped down to 500 volts. The arrangement for controlling the machines may be seen from the coupling scheme shown in Fig. I.

From the switchboard the current is conducted through copper bars laid in cement channels to the 3-phase transformers. The capacity of these transformers is $I, 500$ k.v.a., and their ratio of transformation $14: \mathrm{I}$. By regu- 
lating the tension of the generator the low-tension sides of the transformers can. be altered through small intervals from 20 to 85 volts. The ratio of transformation can be altered to $7: 1$ by means of certain easily performed changes of coupling in the transformers, in which case the low tension can

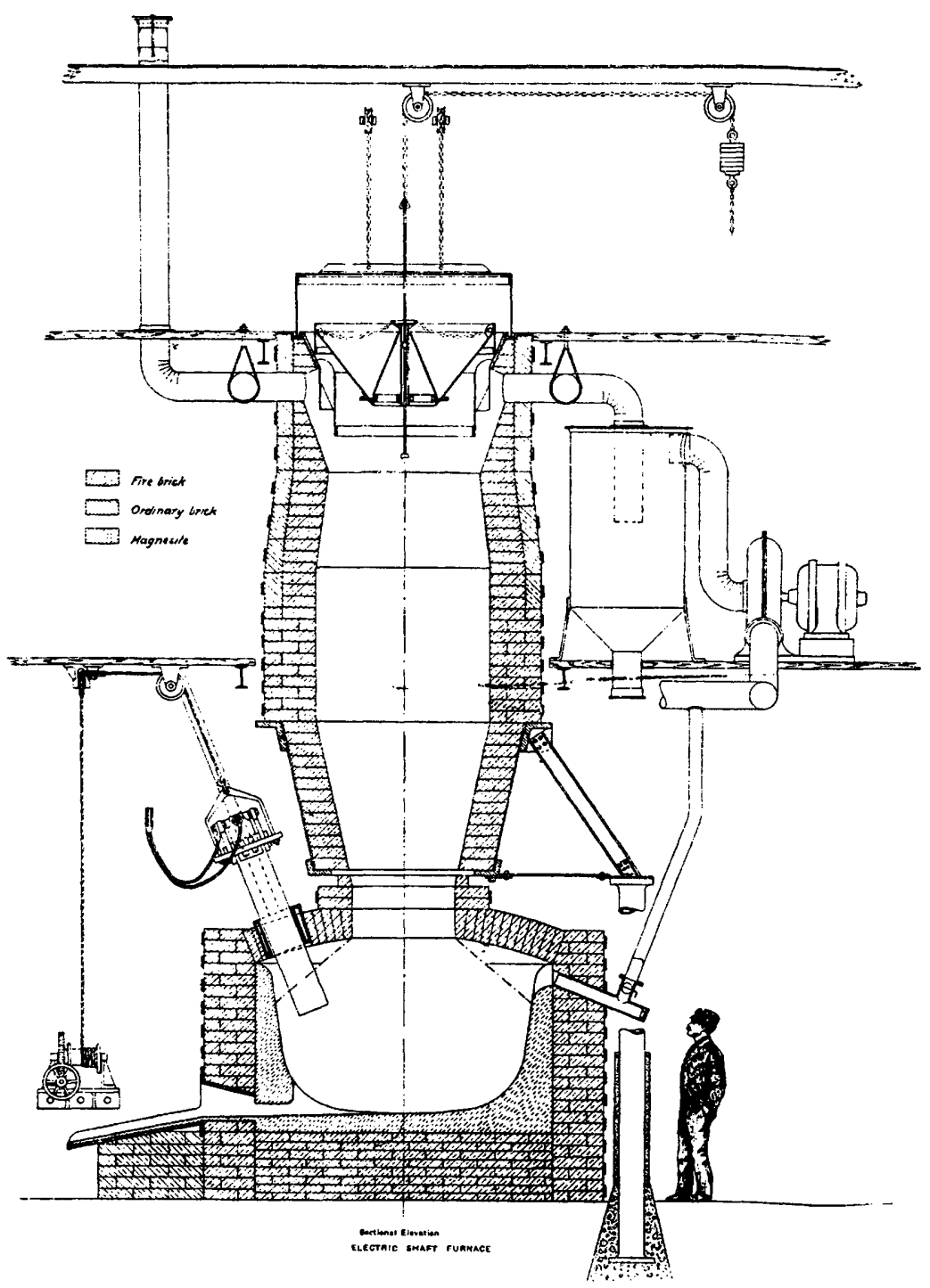

FIG. 3.

be varied between 40 and 170 volts. The transformers are cooled with air supplied under pressure by two electric blowers.

A switcliboard is situated conveniently near the furnace for controlling its operation, on which are mounted the following instruments: I 3-phase precision wattmeter for differently loaded phases, 3 ampere-meters-one for each phase, and I voltmeter. 
The ampere-meters and the wattmeter are connected to the current system by means of transformers. The voltmeter and tension terminals of the wattmeter are directly connected to two of the conducting bars.

\section{Description of Electric Shaft Furxace.}

In general appearance this electric shaft furnace is unlike any hitherto constructed, being very similar in design to an ordinary blast furnace in which the tuyères are replaced by electrodes.

A vertical section of the furnace is represented by Fig. 3, and Fig. 4 shows a top view with the shaft and electrodes removed.

The height of the furnace above ground-level is about $25 \mathrm{ft}$. The melting chamber of crucible containing the electrodes is about $7 \mathrm{ft}$. high, and is of

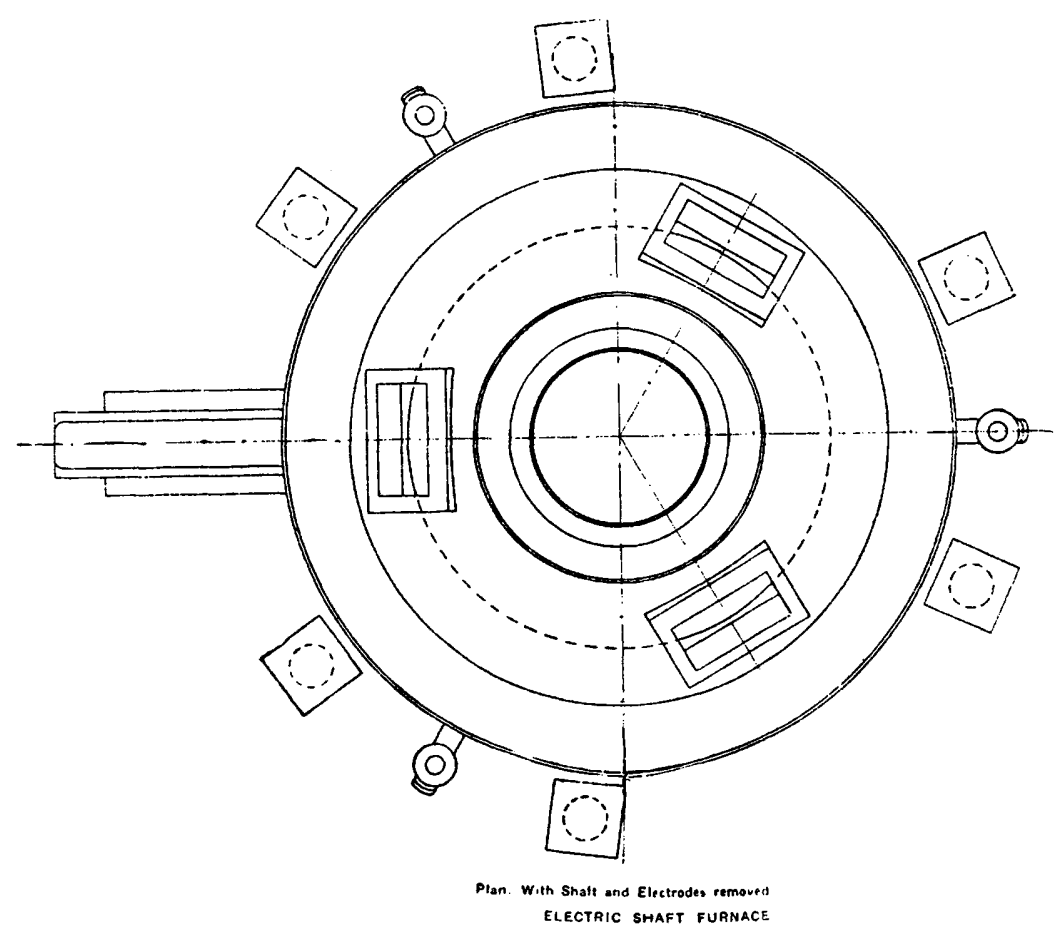

FIG. 4.

greater diameter than any other part. The shaft is about $\mathrm{I} 8 \mathrm{ft}$. high, the lower end of which, for about $4 \mathrm{ft}$., has the form of a truncated cone, for the purpose of directing the charge into the crucible in such a manner that the electrodes, lining, and descending charge could not come in contact. This special feature in the design was introduced by the inventors after repeated experiments, which demonstrated that the upper surface of the column formed by the materials charged into the furnace assumes a definite angle, viz., $50^{\circ}$ to $55^{\circ}$ to the vertical, when the materials-crushed to normal size, and at the same temperature as that existing in the melting chamberare allowed to fall through a circular aperture into a free space. In Fig. 3 the slope is indicated by dotted lines. 
It is this isolation of the descending charge from the lining at the point where the electrode enters the furnace that constitutes the particular economic advantage of the construction, since it prevents the destruction of the lining, which occurred in all previous furnaces where the electrode came directly in contact with the melting charge and the lining, for the temperature of the brickwork in close proximity to the electrodes becomes so great that the most refractory lining materials are rapidly destroyed, even when the electrodes are cooled by water-jackets.

The contracted neck of the shaft immediately over the central opening into the melting chamber is not supported by the arched roof, but the entire weight of the shaft is carried by six cast-iron columns arranged symmetrically round the furnace hearth.

The melting chamber is made in the form of a crucible, and is covered with an arched roof provided with openings for the reception of the electrodes and descending charge. The roof and walls of the crucible are lined with magnesite.

For the purpose of cooling the brickwork composing the lining of the roof of the melting chamber, and thereby increasing its life, three tuyères are introduced into the crucible-just above the melting zone-through which the comparatively cool, tunnel-head gases are forced against the lining of the roof into the free spaces. This gas absorbs heat from the exposed lining of the roof and walls and the free surface of the spreading charge, thus effectively lowering the temperature of the roof and exposed walls.

With the exception, however, of radiation from the tuyeres no heat is lost by this method of cooling, since the heat given up by the lining of roof and wall to the comparatively cool gas introduced through the tuyères is imparted in passing upward through the shaft to the cooler portions of the descending charge. This effects not only a better utilisation of the reducing power of the $\mathrm{CO}$, but, in addition, produces a better distribution of heat throughout the charge in the shaft than in any electric furnaces previously constructed.

The tuyères are provided with sight-holes, covered with mica, through which the interior surface of the arched roof can be observed. By means of this device it is possible to determine approximately the necessary quantity of gas required to effectively cool the roof lining at the mouth of the melting chamber.

Each electrode was built up from two carbons II in. square $\times 63$ in. long, making the total cross-section of the built-up electrodes I I in. $\times 22 \mathrm{in}$. The electrode holder is made of a strong steel frame, forming a support for the wedges, by means of which the copper plates conducting the current from the copper cables are pressed against the faces of the electrode.

The electrode is clamped in the steel frame mentioned above, and slides on two guides, which serve the twofold purpose of keeping the angle of inclination to the vertical constant, and relieving the arched roof of any undue strain which would arise from the weight of the electrode if insufficiently supported. A steel cable, secured to the top of the electrode holder and passing over a system of guide wheels or pulleys to the drum operated by the hand-wheel on the switchboard, serves to lower and raise the electrode, by winding or unwinding the drum.

In order to protect the parts of the electrodes outside the furnace from the oxidising action of the air, a suitable covering is provided.

The water-cooled stuffing-boxes, through which the electrodes enter the melting chamber, are provided with special devices (not shown on the drawing) 
for preventing the gas under pressure within the melting chamber from leaking out around the electrodes.

The shaft, as previously mentioned, is supported by an iron plate, resting on six cast-iron pillars arranged symmetrically around the furnace hearth. To prevent the pillars from being cut off in the event of the molton iron accidently finding its way to them, the lower parts are protected by sand enclosed in a sheet-iron casing.

This mode of construction enables the operator to repair or replace-without removing the shaft-those parts of the furnace needing the most frequent repairs, viz., the lower part of the shaft and the meltingichamber.

In order to collect the waste gases at the throat of the furnace, with the object of utilising them economically, and at the same time to protect the charcoal fuel from premature combustion, the top of the shaft is closed by an iron cover, fitted with a charging bell and hopper, covered in by means of a specially constructed sheet-iron hood, designed to prevent gas explosions caused by the intrusion of atmospheric air into the shaft when a charge is being introduced.

The collected gases at the throat of the furnace are discharged into a downcomer pipe, provided with a dustcatcher, from which the gases, largely denuded of dust, are drawn by means of a fan, and forced down into the melting chamber through the three tuyères.

With a view of preventing excessive pressure in the interior of the furnace, an uptake pipe, provided with loaded, self-closing valve, is placed at the junction of outlet pipe and top of downcomer, for conducting the gases generated in the furnace (when the pressure reaches a certain point) to apparatus designed for the utilisation of the waste gases, or to the atmosphere.

\section{Raw Materials Used.}

The iron ore placed at the disposal of the inventors for the trial run was magnetite from Grängesberg, and had the following composition :-

$$
\begin{array}{llllllllr} 
& & & & & \multicolumn{3}{r}{\text { Per Cent. }} \\
\mathrm{Fe}_{3} \mathrm{O}_{4} & \ldots & \ldots & \ldots & \ldots & \ldots & \ldots & \ldots & 66 \cdot 46 \\
\mathrm{Fe}_{2} \mathrm{O}_{3} & \ldots & \ldots & \ldots & \ldots & \ldots & \ldots & \ldots & 2 \mathbf{I}^{\circ} \mathbf{2 1} \\
\mathrm{MnO} & \ldots & \ldots & \ldots & \ldots & \ldots & \ldots & \ldots & 0 \cdot 30 \\
\mathrm{MgO} & \ldots & \ldots & \ldots & \ldots & \ldots & \ldots & \ldots & 0 \cdot 98 \\
\mathrm{CaO} & \ldots & \ldots & \ldots & \ldots & \ldots & \ldots & \ldots & 3 \cdot 84 \\
\mathrm{Al}_{2} \mathrm{O}_{3} & \ldots & \ldots & \ldots & \ldots & \ldots & \ldots & \ldots & \mathrm{I} \cdot 07 \\
\mathrm{SiO}_{2} & \ldots & \ldots & \ldots & \ldots & \ldots & \ldots & \ldots & 3 \cdot 16 \\
\mathrm{P}_{2} \mathrm{O}_{5} & \ldots & \ldots & \ldots & \ldots & \ldots & \ldots & \ldots & 2 \cdot 34 \\
\mathrm{~S} & \ldots & \ldots & \ldots & \ldots & \ldots & \multicolumn{2}{c}{\text { undetermined }} \\
\text { Metallic iron } & \ldots & \ldots & \ldots & \ldots & \ldots & \ldots & 62 \cdot 96
\end{array}
$$

During the first part of the trial run, coke containing 85 per cent. $C$ and 0.55 per cent. $S$ was used. This, however, had been exposed for a long time to the open air and rain, which made its percentage of moisture unusually high. Lime was used as a flux.

The raw material, crushed to pieces of about $I$ in. diameter, was conveyed to the charging floor of the furnace, where it was weighed, and charged by hand. The instruments were read every half-hour, the product of each tapping carefully weighed, and samples of both the iron and slag taken for analysis. The iron and slag were tapped through the same hole, but no difficulty was encountered in separating the iron from the slag after cooling. 


\section{Heating of the Furvace.}

Notwithstanding the fact that the furnace was new in every respect, only one week was allowed for heating from the time the first coke fire was lighted in the melting chamber to the time of the first tapping. Experience with blast furnaces has proved that at least three weeks should be devoted to the drying of the linings in furnaces of this size, prior to charging ; otherwise, the heat energy which should be utilised in the reduction and dissociation of the ores will be expended in converting the moisture in the brickwork into steam, resulting in the chilling of the iron, and consequent reduction of the output. The unavoidable neglect of this precaution in the present instance interfered materially with the normal thermal working condition of the furnace throughout the entire trial.

\section{Poiver Supplied to the Furnace.}

Although the furnace was designed for a much larger capacity, the power available at this time was only 400 to $450 \mathrm{kw}$. The tension was kept at between 40 and 50 volts, and the power factor-which, with the lower tension during the first part of the run was 0.85 -rose to 0.90 with the higher tension.

A point in the construction of this furnace deserving of special mention is the almost complete absence of fluctuation in the instruments for recording the current and tension delivered. This, in former electric furnaces, occasioned a serious difficulty, and necessitated either the installation of automatic electrode regulators, or the constant presence of a man at the switchboard for adjustment and regulation. In this case, however, the only regulation required is that corresponding to the consumption of the electrodes, which requires to be done once a day, and sometimes for slightly longer periods. The cost of the electric installation for this furnace, compared with that of other types, is, therefore, cheaper, inasmuch as the costly apparatus for controlling the electrodes is dispensed with. Since the fluctuation of power is almost negligible, and current shocks do not have to be taken into consideration, this type of electric furnace constitutes an ideal load for a power station.

\section{The Trial Run.}

The trial run was started at 6.30 a.m., December 27 th, when the readings of the different measuring instruments were taken and recorded every halfhour. Samples of the pig iron and slag were taken for analysis; and the iron -after the slag had been entirely removed-carefully weighed.

During the first part of the trial the composition af the charge was :-

$$
\begin{array}{llllllll}
\text { Ore } & \ldots & \ldots & \ldots & \ldots & \ldots & \ldots & 209 \circ \mathrm{lbs} . \\
\text { Coke } & \ldots & \ldots & \ldots & \ldots & \ldots & \ldots & 4^{\circ} 4 \mathrm{lbs} . \\
\text { Lime } & \ldots & \ldots & \ldots & \ldots & \ldots & \ldots & \text { 1 I } \circ \mathrm{lbs} .
\end{array}
$$

The coke used in this charge corresponds to a consumption of about 810 lbs. per long ton of pig iron. During tapping, however, carbon was observed to escape through the tap-hole with the slag, which, in addition, contained a considerable amount of carbide. This indicated an excess of carbon. The charge was, therefore, altered the next morning to the following composition :-

$$
\begin{array}{lllllllr}
\text { Ore } & \ldots & \ldots & \ldots & \ldots & \ldots & \ldots & 209^{\circ} \circ \mathrm{lbs} . \\
\text { Coke } & \ldots & \ldots & \ldots & \ldots & \ldots & \ldots & 42^{\circ} \circ \mathrm{lbs} . \\
\text { Lime } & \ldots & \ldots & \ldots & \ldots & \ldots & \ldots & 44^{\circ} \mathrm{lbs} .
\end{array}
$$


corresponding to a consumption of carbon of about $704 \mathrm{lbs}$. per long ton of pig iron.

On the evening of the same day the charge was again changed to :-

$$
\begin{array}{lllllllr}
\text { Ore } & \ldots & \ldots & \ldots & \ldots & \ldots & \ldots & 220 \circ 0 \mathrm{lbs} . \\
\text { Coke } & \ldots & \ldots & \ldots & \ldots & \ldots & \ldots & 4 \mathrm{r} \cdot 8 \mathrm{lbs} . \\
\text { Lime } & \ldots & \ldots & \ldots & \ldots & \ldots & \ldots & 4 \cdot 4 \mathrm{lbs} .
\end{array}
$$

which corresponds to a consumption of carbon of about $67 \mathrm{I}$ lbs. per long ton of pig iron.

The coke used up to this time was very wet, having been exposed to rain and snow. As, however, dry coke, which consequently contained a higher percentage of carbon per unit weight, was now available, the charge was again changed to :-

$$
\begin{array}{lllllllr}
\text { Ore } & \ldots & \ldots & \ldots & \ldots & \ldots & \ldots & 220^{\circ} \mathrm{lbs} . \\
\text { Coke } & \ldots & \ldots & \ldots & \ldots & \ldots & \ldots & 37^{\circ} 4 \mathrm{lbs} . \\
\text { Lime } & \ldots & \ldots & \ldots & \ldots & \ldots & \ldots & 44^{4} \mathrm{lbs} .
\end{array}
$$

which corresponds to a consumption of coke of about 605 lbs. per ton of pig iron. This might be further reduced when the furnace is working normally, and the gases circulated as previously described. However, this consumption of carbon must be considered as extremely satisfactory.

Analyses of the pig iron from six different tappings, and of the slag from tapping No. 4, are given below. From an inspection of these analyses it will be seen that the sulphur content, especially in the last one, is exceedingly

\begin{tabular}{|c|c|c|c|c|c|c|c|}
\hline $\mathrm{SiO}_{2}$ & $\cdots$ & $\cdots$ & $\cdots$ & $\cdots$ & $\ldots$ & ... & $\ldots \quad 26 \cdot 54$ \\
\hline $\mathrm{CaO}$ & ... & $\ldots$ & $\ldots$ & $\ldots$ & ... & $\ldots$ & .. 54.48 \\
\hline $\mathrm{S}$ & $\ldots$ & $\ldots$ & $\ldots$ & $\ldots$ & $\ldots$ & $\ldots$ & $\begin{array}{ll}\ldots & 0.78\end{array}$ \\
\hline $\mathrm{Fe}$ & $\ldots$ & $\ldots$ & $\ldots$ & $\ldots$ & $\ldots$ & $\ldots$ & 0.35 \\
\hline
\end{tabular}
low. During the last tapping the temperature of the furnace was higher than in the former tappings, which accounts for the low sulphur content.

Analyses of Pig Iron Produced.

\begin{tabular}{c|c|c|c|c|c}
\hline Cast No. & C. & Si. & Mn. & P. & S. \\
\hline 2 & 3.20 & 0.056 & 0.32 & $\mathrm{I} \cdot 80$ & 0.015 \\
3 & 3.20 & 0.103 & 0.37 & $\mathrm{I} \cdot 50$ & $*$ \\
4 & 3.40 & 0.065 & 0.34 & $\mathrm{I} \cdot 64$ & 0.015 \\
5 & 3.20 & 0.075 & 0.32 & $\mathrm{I} \cdot 80$ & $*$ \\
9 & 3.20 & 0.075 & 0.39 & $\mathrm{I} \cdot 90$ & 0.015 \\
$\mathrm{I3}$ & 3.15 & 0.070 & 0.24 & $2 \cdot 06$ & 0.005 \\
\hline
\end{tabular}

Analysis of Slag from Cast No. 4. 
It may be pointed out that the output continued to rise steadily as the furnace more nearly approached its normal working condition-even with the inadequate power supplied-until an unfortunate accident occurred to one of the water-cooled stuffing-boxes, necessitating the removal of one electrode.

Towards the end of the run one of the cast-iron water-cooled stuffingboxes developed a bad crack, which allowed large quantities of water to escape into the furnace. This would not have occurred had sufficient time been allowed for the thorough testing of all the castings, and cannot happen in the future, since the design of these water-cooled stuffing-boxes has been changed. But even while running with only two electrodes, the output again began to rise when the heat lost by the water escaping into the furnace was partially restored to the walls of the furnace and to the wet charge in the shaft.

In the following table is given the number of tons of pig iron produced per electrical horse-power year, in casts Nos. 2 to Io, inclusive :-

\begin{tabular}{|c|c|c|c|c|c|c|c|c|}
\hline \multicolumn{7}{|c|}{ Cast No. } & \multicolumn{2}{|c|}{$\begin{array}{l}\text { Tons of Pig Iron } \\
\text { per E.H.P. Year. }\end{array}$} \\
\hline 2 & $\ldots$ & $\cdots$ & $\ldots$ & $\cdots$ & $\cdots$ & $\cdots$ & $\cdots$ & 0.744 \\
\hline 3 & ... & ... & ... & $\ldots$ & $\cdots$ & $\cdots$ & $\cdots$ & $I \cdot 870$ \\
\hline 4 & $\cdots$ & $\cdots$ & $\cdots$ & $\cdots$ & $\cdots$ & $\ldots$ & $\cdots$ & $2 \cdot 180$ \\
\hline 5 & $\cdots$ & $\cdots$ & $\cdots$ & $\cdots$ & $\cdots$ & $\cdots$ & $\cdots$ & $2 \cdot 360$ \\
\hline 6 & $\cdots$ & $\cdots$ & $\cdots$ & $\cdots$ & $\cdots$ & $\cdots$ & $\cdots$ & 2.440 \\
\hline 7 & $\cdots$ & $\cdots$ & $\cdots$ & $\cdots$ & $\cdots$ & $\cdots$ & .. & $I^{\circ} 120^{*}$ \\
\hline 8 & $\ldots$ & $\ldots$ & $\ldots$ & $\ldots$ & $\ldots$ & $\ldots$ & $\ldots$ & $3 \cdot 160$ \\
\hline 9 & $\cdots$ & $\cdots$ & $\cdots$ & $\cdots$ & $\cdots$ & $\cdots$ & $\cdots$ & $I^{\circ} 95^{\circ}$ \\
\hline I0 & $\ldots$ & $\ldots$ & $\ldots$ & $\ldots$ & $\ldots$ & $\ldots$ & $\ldots$ & $I^{\circ} 030$ \\
\hline
\end{tabular}

From the foregoing tables it will be seen that the output, before the leakage of water into the furnace became serious, was $2^{*} 44$ metric tons per electrical horse-power year. This figure-considering the disadvantages under which the trial run was made-may be deemed very satisfactory.

Owing to the short duration of the trial, it was impossible to determine the consumption of electrodes per ton of pig iron produced. According to former tests, however, this may be placed at about $5 \mathrm{kgs}$. per metric ton $(2,204 \mathrm{lbs}$.) of pig iron produced.

\section{Technical Objective of Trial Run.}

The trial run was intended to elucidate the following points :-

I. Whether undisturbed and uniform working without troublesome regulation of the electrodes could be obtained.

2. Whether great variations in the consumption of energy would occur.

3. Whether the free spaces within the melting chamber would be maintained with a shaft considerably higher than in the furnaces of earlier design and construction.

4. Whether the contraction of the shaft would prevent the charge from sinking uniformly, or cause hanging.

5. The durability of the arched roof, and the possibility of cooling it by means of the circulating gas.

* Electrode holder began to leak badly. 


\section{Denuctions From Observations.}

The following is a summarised statement of practical deductions drawn from observations made during the trial run-having regard to the objective points specified above :-

(a) It was observed that the furnace operated uniformly and without trouble of any kind, and that the electrodes required absolutely no regulation, in one case, for five consecutive days. In any case, the only regulation required is that corresponding to the consumption of the electrodes, and is necessary only once a day, and sometimes not for much longer periods. On account of this, expensive regulation can be dispensed with.

(b) During the short trial, even though the furnace did not approach its normal working condition until towards the end, it was observed that the consumption of energy was remarkably uniform.

(c) Free spaces were maintained between the linings of the roof and walls, and the electrodes and charge at the openings where the electrodes enter the melting chamber.

(d) It was found that the charge did not jam in the lower contracted neck of the shaft, as had been feared, but moved with regularity into the melting chamber.

(c) Although the gases generated by the reduction of the ore were not circulated through the cooling tuyères until near the end of the trial run, it was demonstrated that the lining of the roof of the melting chamber was effectively cooled by this means.

\section{COMPARISON OF THE COST OF PRODUCTION OF PIG IRON IN THE CHARCOAL BLAST FURNACE WITH THAT PRODUCED IN THE ELECTRIC SHAFT FURNACE.*}

By Professor von Odelstierna, Stockholm, Sweden.

It we take, as a basis for our comparative study, an ordinary charcoal blast furnace, and the electric shaft furnace erected at Domnarfvet, and suppose the iron ore used in these furnaces to contain 60 per cent. metallic iron and the charcoal 83 per cent. carbon, then it should be possible to make a reliable comparison. It should be pointed out, however, that in this com. parison no account is taken of the fact that the gases produced in the electric shaft furnace contain a higher percentage of $\mathrm{CO}-$ probably 60 per cent. more -than the ordinary blast-furnace gases.

In regard to the labour charges and general expenses, I make the supposition that these charges are the same for both the electric shaft furnace and the charcoal blast furnace, if the contrasted furnaces are of such capacity as to produce the same quantity of pig iron per year. A charcoal blast furnace of medium capacity produces in Sweden about 8,000 to Io,000 short tons of pig iron per annum-a quantity which I believe can also be produced in a properly constructed electric shaft furnace of the type of Aktiebolaget Electrometall.

* Based upon conditions in Sweden. 
Cost of Pig Iron per Short Ton in Dollars.

Charcoal Blast Furnace.

Charcoal, o.95 ton at $\$ 8$ per ton $\$ 7.60$

Electrical energy $\quad \ldots \quad \ldots \quad 0.00$

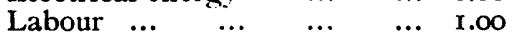

Electrodes $\quad \ldots . \quad \ldots \quad \ldots \quad$... 0.00

Repairs and general expenses $\mathbf{1} .50$

\$10.IO

Electric Shaft Furnace.

$$
\begin{aligned}
& 0.27 \text { ton } \ldots \quad \ldots \quad \ldots \quad \ldots 2.16 \\
& \text { o.3 E.H.P. year at } \$ 12 \ldots \quad \ldots \quad 3.60
\end{aligned}
$$

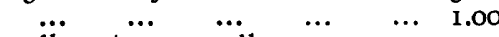

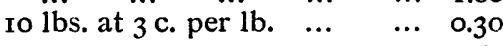

$$
\begin{aligned}
& \begin{array}{lllllll}
\ldots & \ldots & \ldots & \ldots & \ldots & \text { I.50 }
\end{array} \\
& \$ 8.56
\end{aligned}
$$

In this calculation the price of ore and limestone and the royalty are not given, as the former varies with the locality and the character of the ore, and the latter has not yet been determined.

From this calculation it is apparent that in Sweden, under the abovementioned circumstances, a saving of $\$ 1.55$ should be effected in the production of pig iron by the electrothermic process. 